\title{
Correction: Hematopoietic cell transplant in pediatric acute myeloid leukemia after similar upfront therapy; a comparison of conditioning regimens
}

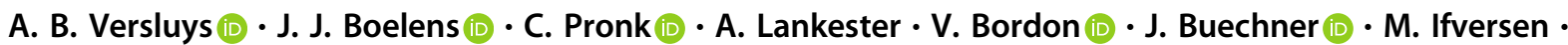 \\ N. Jackmann (1) $\cdot$ M. Sundin (i) $\cdot$ K. Vettenranta $\cdot J$. Abrahamsson $\cdot$ K. Mellgren
}

Published online: 15 March 2021

(c) The Author(s), under exclusive licence to Springer Nature Limited 2021

Correction to: Bone Marrow Transplantation

https://doi.org/10.1038/s41409-020-01201-w.
The original version of this article, unfortunately, contained a mistake. The spelling of J. Buechner's and J. Abrahamsson's names was incorrect. The corrected author list is given above. The original article has been corrected. 